\title{
Internal and External Factors to the Success of the Cuban Revolution
}

\author{
Boyuan Dong \\ University of Toronto \\ FAS, Latin American Studies \& Spanish Specialist
}

\section{A B S T R A C T}

Fidel Castro, the revolutionary leader of Cuba, gave a speech on the fourth anniversary of the Cuban Revolution, mainly focusing on how to solidify the pueblo cubano under the revolutionary flag against the U.S. intervention. This paper aims to examine the Cuban revolution stand on the view from four years after Castro has died, to prove that what Castro has mentioned during his Fourth Anniversary Speech has been accomplished, as well as compare the revolutionary movements of its neighbours like Grenada, to see why Cuba could be the only successful example of socialism in the Western Hemisphere. The paper will focus on the social changes during the post-revolution Cuba based on the scholar research of Louis A. Pérez and John Walton's comparison article between Grenada and Cuba.

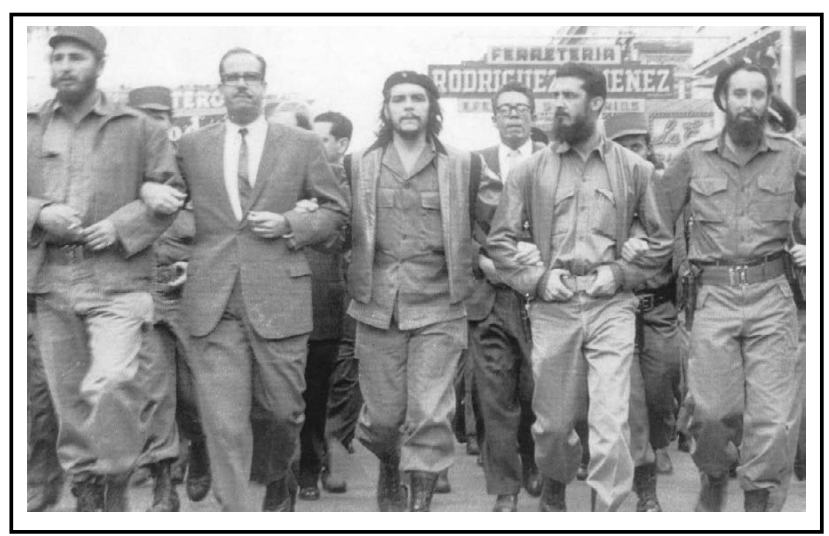

Keywords: US imperialism, Cuban Revolution, Fidel Castro, Cold War,

\section{$\mathrm{B} \mathrm{I} \mathrm{O}$}

Boyuan Dong is a fourth-year undergraduate student majoring Latin American Studies and Spanish. Currently his focus is on the narratives of affection in the contemporary Latin American Literature

(C) 2021 Boyuan Dong

Caribbean Studies Students'Union, Canada - https://jps.library.utoronto.ca/index.php/cquilt/

This work is licensed under the Creative Commons Attribution-ShareAlike 4.0 International License. To view a copy of this license, visit https://creativecommons.org/licenses/by-sa/4.0/ 
On January 2, 1963, one and a half year after the Playa Girón Invasion, before his supporters at Plaza De Revolucion, Fidel Castro gave a speech on what the Cuban Revolution had achieved during the four years since its outset. In his speech, the leader of communist Cuba denounced the former US President John F. Kennedy's speech about the same event. Though both Kennedy and Castro mention the Bay of Pig Invasion, the similarities end there with Castro viewing the event as an imperialist invasion, intended to topple what the pueblo cubano has achieved since 1959. Kennedy saw it not as an invasion but a liberation - with soldiers there to deliver freedom to a place where human rights were violated, interests of the domestic and international stakeholders destroyed, and individual dignity and freedom of expression had been eliminated. ${ }^{1}$

To Kennedy, the state was subjugated under the dictatorship of Castro Castro. While Castro referred Kennedy in his speech as "the chief of pirates" ${ }^{2}$ Kennedy, reproached Castro's post-revolutionary Cuba as a "prison" surrounded by water where six million of the population was imprisoned. According to Castro's speech, Kennedy had disavowed Castro's revolution and all the reforms and campaigns carried on by him, while Castro addressed the revolution was a "victory" and exemplary to the people under the exploitation by imperialism ${ }^{3}$. Though in the speech, Kennedy had negated all that was done by the revolutionary government, it would be unreasonable to deny all the achievements by Castro's government, which by that time was backed by the masses and enjoyed high popularity.

Considering the context of these conflicting narratives, this research seeks to analyze what Fidel Castro speaks about in his Fourth Anniversary Speech considering the accomplishments and the success of the Cuban Revolution in the context of the internal and external factors that pushed forward the revolution. Specifically, this paper considers that internally, Fidel Castro's communist government implemented a series of campaigns and reforms that had visible and immediate improvement to the pueblo cubano and externally, a bipolarized confrontation and hostility helped the Cuban government to solidify its rule.

Fidel Castro quoted Kennedy's speech in his own, telling the audience that Kennedy believed that within the Cuban regime and its army there should be people who "hold to a faith in freedom and are filled with consternation at the destruction of freedom in their island and are determined to restore that freedom so that the Cuban people can again govern themselves" 4 . While concurring, Castro and the Fidelistas had a vastly different approach to the restoration of freedom and self-governance. The elimination of influences from the United States was rapid and visible. The mass nationalization of foreign capitals had won Castro unprecedented support by Cubans who formerly suffered the large income distribution inequality and the exploitation by U.S.

\footnotetext{
${ }^{1}$ Fidel Castro, "Fourth Anniversary of the Cuban Revolution," Castro Speech Database 2000 (Havana: January 2, 1963). https://www.marxists.org/history/cuba/archive/castro/1963/01/02.htm

${ }^{2}$ Fidel Castro, "Fourth Anniversary"

3 Fidel Castro, "Fourth Anniversary"
} 
imperialism ${ }^{5}$. To understand why Castro possessed such popularity, it is necessary to understand the situation in Cuba before revolution. With such, it becomes clear why Castro included an ironic use of Kennedy's phrase "Cuban people can again govern themselves" 6 in his own speech.

The influence of the U.S. in pre-revolutionary Cuba was omnipresent and formidable. While Cuba's major industries and foreign exchange were centered around the production of sugar, Cuba was not able to control its price? ${ }^{7}$ Moreover, its over-dependence on sugar had increased its vulnerability to the fluctuations of the international sugar price. The consequence of losing influence over the market meant that when sugar prices increased, Cuba had a remarkably high cost of living when compared to North America ${ }^{8}$. When sugar prices dropped, foreign investors rushed in and purchased real estate and shares of different sectors such as electricity and telecommunications further violating the sovereignty of the nation. The export-dependent economy was in misery.

According to Pérez, most peasants and sugar field workers "lived in desperate conditions, without access to minimum educational, health, and housing facilities" 9 . With an increasing number of foreign investors holding national properties, foreign business owners were able to gain more influence than local small-scale land owners as well as the Cuban middle class. Local industries faced a strong foreign competition with little or no government restrictions, like tariffs, to protect domestic enterprises ${ }^{10}$ As a consequence of local industries crashing, workers and the middle class found it harder to maintain their lives because of the high cost of living and the scarcity of basic necessities. According to data provided by Pérez, one-fifth of the agricultural land was controlled by large sugar companies and "almost three-quarters of all land in production was held by only 8 percent of the farms (numbering 16,622)",11. The tremendous inequality gave Fidel Castro an opportunity to win over the masses because the people who suffered in this increasingly worsening condition needed someone to lead them and eliminate the foreign influences which they deemed the cause of their misery. Castro promised just that and fulfilled his commitment to become the leader and expel all exploitation that had harmed the Cuban people.

Since Fidel Castro, all properties controlled by Americans now became state-run and he achieved what Kennedy had mentioned - "Cuban people govern themselves" through sectors and properties no longer belonging to the Americans but Cubans. This is why Castro satirized Kennedy in his Fourth Anniversary Speech highlighting Kennedy's comparison between US invaders and the independence heroes like Marti, Bolivar and

\footnotetext{
4 Fidel Castro, "Fourth Anniversary"

5 Fidel Castro, "Fourth Anniversary"

6 Fidel Castro, "Fourth Anniversary"

7 Louis A. Pérez, "Cuba Between Reform and Revolution" (Oxford University Press: 2005). p. 224

8 Pérez, “Cuba”.p. 224

9 Pérez, "Cuba".p. 224

10 Pérez, "Cuba".p. 225

11 Pérez, "Cuba”.p. 229
} 
O'Higgins ${ }^{12}$, whom Castro thought of as freedom fighters. To do so, Castro incisively pointed out the differences between these independence symbols and the intruders:

"Marti who did not receive his funds from the Yankee treasury [...] Of that Marti who did not come escorted by the Yankee fleet, nor was he preceded in his landing by Yankee bombers, of that Marti who on a stormy night landed in a rowboat almost by himself on the western shores" 13

Beyond the recovery of sovereignty through the expelling of foreign presence after the revolution, a series of reforms and campaigns (mainly agrarian reform and literacy campaigns) have also been widely considered as improvements that Fidel Castro's government achieved. The land left by foreign investors was put to reuse after nationalization through the division of land to diversify national production. For large sugar mills, land that exceeded a given limit was nationalized, with compensation given by the government "in the form of twenty-year bonds bearing an annual interest rate of 4.5 percent" ". Nationalized land was redistributed to state-run corporations or individuals with no land holdings while the communist committee also established the Instituto Nacional de Reforma Agraria (INRA) $)^{15}$ in order to supervise and enforce the redistribution and production of land.
During the nationalization, Castro did not face the difficulties many expected, because within the Cuban bourgeoisie class and the foreign capitalists there were internal conflicts. Landlords, large company owners, sugar exporters failed to cooperate unanimously against Castro's policies. Each one only focused on their own narrow interests and were frequently in conflict with other members of the bourgeoisie class ${ }^{16}$. It gave Fidel Castro chance to break the entire upper class of Cuba when "the internal opponents were in disarray" and recover all properties under the name of the revolutionary republic.

Cuba also carried a thorough literacy campaign that none of the former governments were able to achieve. This contributed to the popularity of Castro and the success of the revolution. Castro described in his speech these literary campaigns carried out as part of the revolution. Students were dispatched to rural areas as volunteers to teach, fees were afforded by the government, elementary education became more universal, and higher education was no longer a privilege accessed only by middle to upper class families. In 1958, "almost half of all Cuban children aged six to fourteen years had received no education. Only a quarter of the population of fifteen years or older had ever attended school"18. The comparison before and after the revolution is surprising, as Pérez mentions:

\footnotetext{
12 Fidel Castro, "Fourth Anniversary"

13 Fidel Castro, "Fourth Anniversary"

14 Pérez, “Cuba”.p. 243

15 Pérez, "Cuba".p. 243

16 Pérez, “Cuba”.p. 253

17 Pérez, "Cuba".p. 245

18 Pérez, "Cuba”.p. 273
} 
"Almost 30 percent of the population of color over twenty years of age was illiterate [...] They suffered greater job insecurity, more unemployment, poorer health care, and constituted a proportionally larger part of the prison population. They generally earned lower wages than whites". 19

In March 1959, Castro's government legally abolished racial discrimination in all sectors. From education to entertainment and tourism, services were open to people of colour, which provided an immediate relief to the tensions in the society. Income has been redistributed with an increase in workers and non-white people and a decline in landlords and officials ${ }^{20}$.The disparity of income and literacy rate between cities like Havana and rural areas had decreased. During the campaign, thousands of men and women were mobilized across the island to eradicate illiteracy, which was praised by Castro as the revolutionary spirit of the Cuban people. As a result, by 1962 Cuba had reported a literacy rate of $96 \%$ - one of the highest in the world.

A series of successful campaigns and reforms had proved that Castro's government was built to govern by the people and serve the people. Properties owned by the government officials of the former Batista government were all seized. Peasants received lands and education, ciudadanos got jobs, and non-whites acquired protection. Virtually all sectors had witnessed an increase in benefits and wages while luxury imports were restrict- ed by the government in order to save foreign exchange, which was used to improve health and industrial sectors 21 Direct and immediate relief to the society gave Castro the supreme authority to rule the island and mobilize the people who followed his ideology. This was demonstrated in American pop-culture and the 1974 film The Godfather II where character Michael Corleone sees a guerrilla fighter using a suicide attack to kill a Batista official, and notes: "The soldiers are not paid to fight. The rebels aren't. They could win" 22

In Castro's speech, he had denounced the version of "Free Havana" and "Real Cuba " suggested by John F. Kennedy, whose anti-communist ideal of Cuba deferred from Castro's ideology of the method by which Cubans could and would govern themselves moving forward. The Free Cuba that Castro deemed a successful accomplishment was not recognized by the U.S. government nor the Cuban diaspora in the U.S. - especially in epicenters of Cuban culture like Miami. The definition of Free Cuba has raised an immense discussion among Cuban Americans. For example in 1999, they centered around whether the U.S. government should return Elian Gonzalez to his father in Cuba. Elian was a six-year-old boy who crossed the sea to enter the U.S. illegally from Cuba with his mother. While his mother died when their motorboat sank during the crossing, he had survived the accident, saved by fishermen in that area. His uncle in the U.S. saw him as a miracle and a survivor from the Castro's Cuba and

19 Pérez, “Cuba”.p. 233

20 Pérez, "Cuba".p. 244

21 Pérez, "Cuba".p. 243

22 Francis Coppola, “The Godfather Part II”, directed by Francis Ford Coppola, (New York City: Paramount Pictures, 1974) 
wanted him to stay in the U.S.. The event was quickly known by the Cuban-American community, who had defended and protested to prevent the U.S. government from returning the boy to Cuba and his father. It dramatized, according to Lilian Guerra, the "creation and growth of what many Miami Cubans understand to be the 'real Cuba' in the U.S.' 23

The Cuban exiles in the U.S. did not recognize all achievements done after the revolution because they deemed themselves more Cuban than island Cubans. To them - just like Kennedy - Castro had changed the island from Cuba to a prison, and all who supported Castro and the revolution were automatically deprived of their Cuban identity. Thus, the problem was not merely whether the boy should be returned from the "real Cuba" to Castro's regime but rather a question of "If Castro wants the boy, then we could not give the boy to him". Most Miami Cubans ignored the literacy campaign, the raise of wages and agrarian reforms carried out successfully by the revolution because they were against Castro himself, thus all he had done they would oppose. For many of the exiles, Elian's event showed that "the alternative patria, the "real Cuba", had finally been born" ${ }^{24}$ Each side of the island Cubans and Miami Cubans considered the other traitors who did not live in "Free Cuba". For the exiles, staying on the island and tolerating the revolution was passively admitting the legitimacy of Castro's version of "Free Cuba", which was considered an action of treason even if the majority of Cubans had chosen to stay on the island and defend the success that allowed Cubans to govern themselves on the island for the first time. To them, the Cuba of Cubans could only be achieved outside of Castro's power and protected by democratic and anticommunist values, such as in the those Castro.

The Cuban exiles in Miami have intentionally ignored the impact of U.S.. interventions and its support of dictators as an avenue to protect its interests on the island since the 1901 Platt Amendment. The U.S.. presence in Cuba, which was erased by Castro, had impeded moderate political change facilitated through the collusion with local capitalists, elites and military dictators. Another reason that the Miami Cubans could not see objectively the net positive benefits of the regime was because many of them were supporters of former dictator Fulgencio Batista, whose interests in Cuba had been expropriated by Fidel Castro. Their identity and their building of a "real Cuba" proposed by President Kennedy neglected "Cuba's neocolonial history and the Revolution's nationalist goals and socialist policies" 25 as well as the half century of the U.S. occupation and domination in Cuba. When Castro made fun of Kennedy in his speech quoting that "this flag will be returned to this brigade in a free Havana", he revealed that the Cubans in the U.S. were exploiters and accomplices of the U.S. neo-imperialism who failed to attain their interests within Cuba after the revolution. They, as only a small number of the Cuban population, could not foresee the inevitability of the Cuban revolution which was

\footnotetext{
${ }^{23}$ Lillian Guerra, "Elián González and the 'Real Cuba' of Miami: Visions of Identity, Exceptionality, and Divinity,” Cuban Studies, Vol. 38, 2007

${ }^{24}$ Lillian Guerra, "Elián González", p. 4

25 Lillian Guerra, "Elián González", p. 18

${ }^{26}$ Castro Castro, "Fourth Anniversary"
} 
backed by the Cuban peasant workers who outnumbered them. They stood for their class identity rather than their national identity, which left their political view of the "Real Cuba" or "Free Havana" at odds with the majority who benefitted from Castro's policies.

In addition to the internal reasons that determined the success of the Cuban Revolution, the external reasons have also contributed an important factor to the survival of the Cuban revolutionary government. After the U.S. has decreased the export quota of Cuban sugar to zero, Cuba allied with the Soviet Union (USSR), who offered its support to Cuba. Cuba purchased refined oil from the USSR and Cuba's sugar was purchased by USSR. The Soviets provided not only material and financial aids but also technical assistance to construct Cuban national industrial enterprises such as telecommunication, transportation and mining. According to Perez's research, the "Soviet assistance was instrumental in building and modernizing an estimated 160 industrial enterprises"27. The outside support from the Soviet Union also provided quintessential relief to the shortage of food and medical facility supplies in Cuba. It helped the elimination of malnutrition in Cuba by guaranteeing a minimum daily foodstuff ration and "at least one hot meal at work canteens, school cafeterias, and

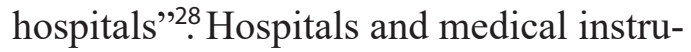
ments were also built in rural areas, improving the equality of allocation of resources between Havana and rural areas.
Cuba's success in transitioning from what was virtually a U.S. colony to a communist nation is hard to duplicate in regionally. The Cuban example is unique in international politics and has served as an outlier in Caribbean revolutionary thought. Considering the most similar example regionally, the following comparison between Cuba and Grenada highlights the extent of Cuba's ability to withstand American hegemonic influence. Firstly, the leader of the Cuban Revolution was also a military leader. Castro had formed guerrilla troops loyal to him before the Cuban Communist Party (CCP) was established. He was the head of the army as well as the head of the party. It allowed him to gain the power to enforce the reforms and campaigns carried out and eliminate his opponents within the island and foreign powers who wanted to topple the regime. Grenada had the communist movements the New Joint Endeavor for Welfare, Education and Liberation (the New Jewel Movement or NJM). Its leader Maurice Bishop did not possessed any military forces. As a result, while the movement was able to achieve a 'bloodless coup' it was not able to withstand U.S. military pressure when it eventually arrived. Bishop and the NJM allied with other parties to form the opposition in the 1976 election. As Collins mentions, Bishop tried to "agitate as part of an official parliamentary opposition" 29 until in 1979, he seized the nation when the former PM Eric Gairy was away at the UN in New York. The NJM gleaned control of Grenada by a coup d'etat but not a revolution, which means Bishop seized power

\footnotetext{
${ }^{27}$ Pérez, “Cuba”.p. 271

28 Pérez, "Cuba”.p. 275

${ }^{29}$ Merle Collins, "Are you a Bolshevik or a Menshevik? Mimicry, Alienation and Confusion in the Grenada Revolution," Interventions 12 (1) 2010, p. 38
} 
from "within the rule", a less violent and radical path compared to Cuba. Bishop was not able to eliminate his opponents completely and defend himself from foreign power because he was a party leader and did not fully control the defense force of Grenada, which made military officials more likely to cooperate with the U.S.. during the US subversion in 1983.

Secondly, Grenada's former metropole, the UK, still had the power of projecting its influences in the Caribbean while Cuba's former metropole was not able to. After taking the nation, the NJM threatened to "nationalize British economic interests in the Caribbean, which were seen as comparable with the UK's investments in India" 30 According to the document from the National Archives in London and Overseas Policy Committee of the Britain's Defence Secretary has an identical plan of invading Grenada once Eric Gairy's government was toppled ${ }^{31}$. While it is true that since the end of WWII Britain has granted independence for many of its former colonies, the newly independent nations in the Caribbean such as Jamaica, Grenada, and The Bahamas still faced immense foreign influence. As Miller suggested, the capital investment of UK in the Caribbean "which may be at risk from nationalization, of at least $£ 250$ million" which would be larger if "banking, insurance and oil industry" were included ${ }^{32}$. Cuba avoided this colonial influence as the former metropole of Cuba, Spain, had just ended the military dictatorship of Francisco Franco and was focused on its path to democratization. Spain's presence in
Cuba, a colony it had left some sixty years before, was almost negligible. Thus, the international environment faced by Grenada was much more difficult than Cuba. Cuba could ally with the USSR without too much scruple while Grenada had to consider the consequence of its embrace of communism in perspective of not only the US but also the UK.

Thirdly, Cuba's geographical importance and natural resources were more important than Grenada, which made it able to attain support from the USSR as a vanguard to counter capitalism. Fourth, Cuba was the first country to have a socialist revolution which the U.S. was not too much aware of. After Cuba, the caution of the expansion of communism of the U.S. became much higher. To let the case of Cuba not happening again, the U.S.. has increased its control over Latin America and the Caribbean to prevent "consequent political instability in the area which could be exploited by Cuba and other opponents of the United States" ". After Cuba, the intention of the U.S.. to subvert any possible socialist or communist reform and revolution was reinforced.

Combining the various internal and external factors above, one may begin to understand why Fidel Castro considered the Cuban Revolution as a victory. The revolution carried out a series of campaigns that effectively benefited the vast majority of Cubans. Income equality, health care and education were provided in spite of race, class, gender. The gaps between cities and rural areas had been

\footnotetext{
${ }^{30}$ Pérez, "Cuba".p. 271

31 Pérez, "Cuba".p. 275

${ }^{32}$ Merle Collins, "Are you a Bolshevik or a Menshevik? Mimicry, Alienation and Confusion in the Grenada Revolution," Interventions 12 (1) 2010, p. 38

${ }^{33}$ Phil Miller, The Secret Story, p. 106
} 
had been reduced. The people were united under the revolution with a strong leader that had eliminated their opponents and foreign power. Cuba was able to gain support because it was strong from within. The support from the Soviet Union was a factor but not the reason of the success 34 Seizing its ideal opportunity, the Cuban revolution was successful and it will inevitably remain successful - just as Fidel Castro has mentioned in his Fourth Anniversary Speech.

\footnotetext{
34 Pérez, “Cuba".p. 253
} 


\section{Works Cited}

Alvarez Nazario, Manuel. 1996. Arqueologíia Linguística: Estudios Modernos Dirigidos Al Rescate Y Reconstrucción Del Arahuaco Taínno. San Juan: Editorial de la Universidad de Puerto Rico.

Arrom, Juan Jose. 2000. Estudios de Lexicología Antillana. San Juan: Editorial de la Universidad de Puerto Rico

Feliciano-Santos, Sherina. "Prophetic Repairs: Narrative and Social Action among Puerto Rican Taíno.” Language \& Communication 56 (2017): 19-32.

Feliciano-Santos, Sherina. "How Do You Speak Taíno? Indigenous Activism and Linguistic Practices in Puerto Rico.” Journal of Linguistic Anthropology 27, no. 1 (2017): 4-21.

Feliciano-Santos, Sherina. "Negotiation of Ethnoracial configurations among Puerto Rican Taíno Activists.” Ethnic and Racial Studies 42, no. 7 (2019): 1149-1167

Feliciano-Santos, Sherina. "An Inconceivable Indigeneity: The Historical, Cultural, and Interactional Dimensions of Puerto Rican Taíno Activism." University of Michigan Press (2011): 1-326.

Forte, Manuel. 2006. The dual absences of extinction and marginality-What difference does an Indigenous presence make? "Indigenous resurgence in the contemporary Caribbean: American Indian survival". New York, NY: Peter Lang.

Granberry, Julian, and Gary Vescelius. 2004. Languages of the Pre-Columbian Antilles. Birmingham: University of Alabama Press.

Haslip-Viera, Gabriel, ed. 2001. Tanno Revival: Critical Perspectives on Puerto Rican Identity and Cultural Politics. Princeton, NJ: Markus Wiener.

Kirtiklis, Kę. "Manuel Castells' Theory of Information Society as Media Theory." Lingua Posnaniensis 59, no. 1 (2017): 65-77.

Makepeace, Anne, dir. 2010. We Still Live Here (Âs Nutayuneân). Bullfrog Films.

Neeganagwedgin, Erica. "Rooted in the Land: Taíno Identity, Oral History and Stories of Reclamation in Contemporary Contexts." AlterNative: An International Journal of Indigenous Peoples 11, no. 4 (2015): 376-88.

OhIfearn, Tadhg. "Sociolinguistic Vitality of Manx after Extreme Language Shift." International Journal of the Sociology of Language (2015): 45-62.

Rumsey, Alan. "Wording, Meaning, and Linguistic Ideology." American Anthropologist 92 (1990): 346-361. 